Studia Anglica Posnaniensia 49/4, 2014

doi: 10.1515/stap-2015-0009

\title{
THE SIGNIFICANCE OF SPACE IN IRIS MURDOCH'S THE UNICORN AS A TWENTIETH-CENTURY IRISH GOTHIC NOVEL
}

\author{
JOANNA JARZAB
}

Adam Mickiewicz University, Poznań

\begin{abstract}
During the twentieth century almost all literary genres came back to prominence in different and alternative forms. The Gothic is no exception to this phenomenon as many a writer made an attempt at using this eighteenth-century genre once again, but adding to it some contemporary elements. Consequently, an abundance of new techniques have been introduced to Gothic fiction to evoke the feeling of horror and terror among the more and more demanding readers of modern times. Still, some writers prefer to return to the traditional concept of the Gothic - as does Iris Murdoch in her novel The Unicorn. The purpose of this article is to analyse the text from the perspective of the Irish Gothic. Those features of the genre which are traditional as well as local are going to be discussed in the context of space as the dominating aspect of the novel. The typical Irish landscape abounding in marshes, bogs and the sea will be contrasted with the inner space of the house, and its resemblance to the old Victorian mansions popular among the Anglo-Irish ascendancy of nineteenth-century Ireland. In what follows, the paper aims at showing how Murdoch's skilful play with the spatial differentiation between the inside and the outside dislodges other more universal issues, such as the question of freedom, of social taboos and of the different anxieties still present in Irish society today.
\end{abstract}

Key words: Irish fiction, Iris Murdoch, Gothic, big house novel

The majority of critical enquiries about Iris Murdoch focus on her novels' philosophical perspective, and thus critics are usually preoccupied with a search for universal messages, treating the setting as a mere background for presenting moral stances. The latest monographs illustrate the on-going interest of critics with the writer's philosophical works, such as Justin Broackes (2011), Maria Antonaccio (2012), or Sofia de Melo Araujo and Fatima Vieira (2011), just to 
name the few. ${ }^{1}$ The interest in the literary side of Murdoch's writing career seems to be waning. Those, who have scrutinized the fiction of Murdoch, like Bradbury (1973), point to the fact that almost all of Murdoch's novels are set in England and that in her writings she refers predominantly to English traditions. Due to this fact, they tend to argue that, despite her background, she ought to be perceived as an English novelist. Murdoch, indeed, spent most of her life in England, but she was actually born in Dublin and after leaving Ireland revisited it several times during her childhood. Throughout her life, Murdoch always took pride in her Irish roots as well as her Anglo-Irish background she shared with Elizabeth Bowen. ${ }^{2}$ Although Murdoch remained predominantly preoccupied with the implementation of her philosophical inquiries into her narratives, she did nonetheless devote some time in her writing to Irish matters as well. Both The Red and the Green (1965) and The Unicorn (1963) are treated as Irish novels, with the first of these being a presentation of The Troubles. Yet it is the typical Irish setting that makes the latter stand out among her other works influenced by the Gothic, such as The Italian Girl (1964) and The Time of the Angels (1966). ${ }^{3}$ The purpose of this paper, therefore, is to reveal the Irish specificity of The Unicorn from the perspective of the Gothic tradition. The analysis will use traditional features of the genre, namely, those established by such writers as Walpole, as the point of reference to discuss the significance of the Irish elements in the context of space as the dominating aspect of the novel. The Irish landscape, abounding in bogs, cliffs and the sea, will be contrasted with the inner space of the house in order to show Murdoch's skilful play with the spa-

1 Justin Broackes as an editor of the monograph Irish Murdoch. Philosopher (2011) has collected articles where attention is focused on the philosophical works of Murdoch, some of them referring to the novels like The Black Prince or Under the Net, treating them as exemplifications of Murdoch's philosophical interests. Maria Antonaccio in A philosophy to live by: Engaging Iris Murdoch (2012) devotes her attention solely to the philosophical side of Murdoch's life; whereas Sofia de Melo Araujo together with Fatima Vieira are the editors of Iris Murdoch. Philosopher meets novelist (2011), where the authors of their articles draw parallels between Murdoch's fascination with philosophy and her literary life in general.

2 Peter Conradi in his biography of Iris Murdoch points out that the writer from her father's side descended from a Protestant Scot-Irish family, who moved from Galloway to Ulster in the seventeenth century (Conradi 2001: 4). Therefore they represented a typical group of Scottish immigrants, who due to the Cromwellian policy were encouraged to populate the north of Ireland and provided with land taken from the Irish gentry. From her mother's side, Murdoch is said to have descended from Alexander Richardson, who was sent by Cromwell to take control over the southern part of the island (Conradi 2001:16). This fact provided Iris with a gentry background, that she took pride in during her life.

3 The majority of critical enquiries point out that female imprisonment, oppression as well as complicated and dysfunctional family relationships are typical features of Murdoch's Gothic novels. The Italian Girl is based on the "Oedipal drama", which takes place in a family; whereas The Time of the Angels presents the Gothic villain - Carel, who is both a father and a priest and a motherless heroine - Muriel (Johnson 1987: 65-66). 
tial differentiation between the outside and the inside. The characters' struggle with the feeling of entrapment caused by the clash between open and confined spaces serves the purpose of introducing the question of their physical and mental state of freedom. In what follows, the paper aims at showing that the Irish setting, present in the text, not only functions as a form of embellishment, but also comments on the taboos and anxieties still prevalent in contemporary Irish communities.

The Irish Gothic has a long and rich tradition, which goes back to the eighteenth century. Writers such as Sydney Owenson or Charles Robert Maturin decided to follow the interest in Ossianism and the sublime, as well as to use wild landscapes, and popular superstitions together with "native insurgency" to produce the Irish version of Gothic fiction (Kilfeather 2005: 80). In order to make the setting typically Irish, they changed the place of action by adding elements of the local landscape such as bogs, cliffs, or the sea - all these immense unpopulated areas, which are reminiscent of a pre-industrial Ireland. The bog lands, by comprising over sixteen per cent of the whole island, have become a landmark of the Irish countryside (Alexander 1989: 54). As Alexander points out, bogs in the Irish context have always fulfilled a crucial cultural and social role in the life of local communities. A bog constituted a natural barrier, preventing people from exploiting the land, and defending its inhabitants against enemies. What is more, the bogs were often used as a source of fuel, or even a hiding place for treasure and bodies (Alexander 1989: 55). However, due to their treacherousness, bogs have become associated with desolate and dangerous places, and therefore are seen as strengthening the image of the isolationism of their nearby areas.

Another feature illustrative of traditional Gothic fiction are castles or monasteries, prevalent in the English Gothic, but which in the Irish context were replaced by big Victorian houses symbolizing the Anglo-Irish ascendancy. The Irish Big Houses comprised the physical traces of the nineteenth-century English dominion over Ireland, which had its beginnings in the seventeenthcentury Ulster plantation movement (Rauchbauer 1992: 2-5). The gradual process of dispossessing Catholic Irish landowners of their lands was followed by the act of giving the land over to the Protestant newcomers from Scotland, England and Wales. This marked the beginning of a deeply rooted denominational conflict, which still prevails in some areas of Ireland today. Although the houses were inhabited by landlords of different origins, including a number of Irish aristocrats, with time they became an epitome of Protestant ascendancy. Thus, during the civil war, the majority of Big Houses were treated by Republicans as a symbol of the English dominance over Ireland, and consequently were set on fire. The rest were abandoned by their owners who fled to England. Interestingly enough, the Big House became a literary trope only 
when it started passing into oblivion as a real place (Genet 1991: $\mathrm{x}$ ). Thus, in Irish literature the notion of the Big House stands not only for the difficult past but more importantly for the gradually disappearance of the Anglo-Irish community. One of the most prominent Gothic writers, C.R. Maturin, was an Irish member of the ascendancy. Together with other representatives of this group he started to depict the life and culture of the Big House once he realised the inevitability of the decline of this community (Fiérobe 1991: 71). Therefore, the Big House stands for social isolation and the desire for selfsufficiency of its owners, which is visible in the architecture of the house itself as well as the surrounding area (Kreilkamp 1998: 9). The houses more often than not are surrounded by walls together with natural barriers such as bogs, hills, or forests. The very genre of the Big House novel is, likewise to the Gothic one, formulaic in nature. Vera Kreilkamp scrutinizes four main features that for her constitute the essence of Big House fiction. Firstly, the state of the house plays a pivotal role as the epitome of the declining AngloIrish class. Secondly, the constant absence of a landlord causes the gradual decay of the house as well as the loss of order, security and permanence of family life. Thirdly, the Big House wife is the main character of the novel, whose loneliness and isolation become the norm of her life. The last element comprises a person from the outside, who usurps the control of the Big House from its heirs (Kreilkamp 1998: 21-24). The complexity of the Big House motive enriched Irish Gothic fiction with additional overtones, especially the hidden truths about a family's past, and the social as well as political contexts.

The list of Irish features does not end on the trope of the house, as some writers also enhanced Gothic imagery with elements from the Irish folk tradition being full of supernatural beings, whose epitome is the presence of fairies. The fear of Catholicism, embellished in many English Gothic novels, in its Irish version, took the form of reactionary communities behind the times, but at the same time rebellious and hostile towards the English newcomers (Foster 2005: 7). From these early times, many a writer has been inspired by the Irish landscape or has incorporated Irish folk tales into their Gothic stories. Murdoch, likewise, was following in the steps of William Larminie, Sheridan Le Fanu, Bram Stoker, or Elizabeth Bowen, just to name a few. In her fiction from the 1960s, Iris Murdoch goes back to Irish Gothic tradition and employs her Irish experience to create a Gothic novel of her time (Todd 1984: 15). Contrary to the new techniques introduced by the authors of science fiction or horror stories, which focus on the Other, Murdoch seems attached to traditional Gothic devices in order to look inward and explore the nature of a human being (MacAndrew 1979: 248). In his analysis of Murdoch's The Unicorn, Guy Backus scrutinizes possible literary sources of the novel. For the critic, Murdoch's work bears resemblance to Sheridan Le Fanu's Carmilla, since the two texts are likewise 
grounded on the motif of the subsequent prevalence of three feelings: "fear, pleasure and disgust" (Backus 1986: 144). For the critic, by experiencing "the pleasing terror", caused by the unpredictable behaviour of the female protagonists, readers are open to the new impressions (Backus 1986: 154). In this way, she continues the eighteenth-century Gothic fascination with the dark side of human nature, namely, with the sources and representations of evil. The writer investigates the desire to control, to manipulate and to exploit others, all of which are often kept under the masque of such feelings as love (Horner 2010: 71). Following the Biblical idea that "the sins of fathers are visited on their children" (Walpole 1968: 41) she also shows how young people become affected by the life of former generations. The aftermath of the past events, which took place in Ireland, are still present in society's consciousness, so that they make the Irish pay for the sins committed by former generations (Byatt 1976: 7). By incorporating all these devices into her fiction, Murdoch not only comments on universal aspects of the human condition, but her Gothic novels may also be analysed with reference to more contemporary social matters.

Murdoch's The Unicorn, apart from its use of more universal Gothic characteristics, such as dysfunctional family relationships or female oppression, features many elements typical of the Irish Gothic. The first is the setting, which plays a pivotal role in the novel. The writer sets the action in a remote place surrounded by fields, the sea, cliffs, and the immense area of bogs, which all together create a picture of a hostile landscape, which for Backus becomes anthropomorphised (Backus 1986: 150). This seemingly open space is contrasted with the enclosed space of the house. Gaze Castle is a typical old Victorian house that bears a resemblance to the Anglo-Irish Big Houses. The trope of the Big House results not only from the author's own Anglo-Irishness shared with Elizabeth Bowen, but also from Murdoch's visit to the famous Bowen's Court in 1956. The place, so much adored by W.B. Yeats, became a source of inspiration for Murdoch. Treating it as an epitome of the declining Protestant Irish aristocracy, Murdoch had the possibility to witness the public life of the place in its final days. ${ }^{5}$ In the novel, Murdoch incorporates all four major features of the Big House convention, namely, the house, the absent landlord, the isolated wife, and the newcomer who tries to impose her perception of reality on the inhabitants. The two families living in the nearby houses, the Crean-Smiths and the

4 In the preface to the first edition of The Castle of Otranto, Horace Walpole explains that the death of the characters should be analyzed on the basis of the words quoted from the Book of Exodus 20:5 (Walpole 1968: 41).

5 Peter Conradi notes that three years after Iris's visit to Bowen's Court, the estate was sold. During her stay, the writer had an occasion to meet Lady Ursula Vernon, daughter of the second Duke of Westminster. Those who knew her claimed she became the model for Hannah Crean-Smith from The Unicorn (Conradi 2001: 398). 
Lejours are probably the last descendants of the Anglo-Irish landlords or the representatives of the new class who, after the civil war ended, started to buy up the abandoned houses. Murdoch also introduces into her novel local inhabitants who are reserved or sometimes even hostile to the English newcomer. Apart from their reactionary attitude towards the strangers, they are said to have "fairy blood" (Unicorn, 47), which may refer to the so called 'Irish Protestant Magic' of those Irish protestants who lost political and economic power, and who thus try to compensate for their loss with "seeing the world in ways that appear to others fey, superstitious and occult" (Conradi after Murdoch 2010: 58). By incorporating both Irish and traditional Gothic elements into the novel, Murdoch successfully creates an atmosphere of the sublime.

The novel tells the story of a young English woman, Marian Taylor, who, estranged from her former partner, Geoffrey, takes up the post of a governess in the remote Gaze Castle. She is supposed to be teaching a child, but once there she is asked to become the tutor of Hannah Crean-Smith, the mistress of the house. Thanks to the servants, Marian learns that Hannah is kept imprisoned in the house by her husband, who went to New York after her failed attempt at killing him by pushing him over a cliff. Under the constant guardianship of Gerald Scottow, her husband's former lover, Hannah is unable to meet with her own lover, Phillip, who lives in the neighbouring Riders house together with the rest of the Lejour family. Another character introduced into the novel is Effingham, Philip's friend. He comes several days after Marian's arrival and stays at the Riders' house. He is the only person from outside of the Gaze Castle who is allowed to visit Hannah. Effingham together with Marian try to organize an escape for Hannah from her imprisonment. No matter how the others try, however, the mistress cannot cross the symbolic border, separating the outside of the house from its inside. After an unfruitful attempt to rescue her, Hannah is locked in the attic by Gerald, whereas the furious Effingham seeks consolation in the bogs, where he nearly drowns. The climax of the story comprises the return of Mr Crean-Smith. Hannah commits suicide for fear of his arrival. At the same time, Denis, her servant, trying to free his lady from her oppressor, carries out the desperate act of causing a car accident. The car with Mr CreanSmith inside falls down the cliff and into the sea. All these terrifying events make Marian leave the place and go back to England.

Murdoch, who is well-known for the unpredictability of her narratives, relies heavily on her books' settings as well. The presence of the Gothic landscape in The Unicorn is visible from the very first pages when Marian arrives at Gaze Castle. The romanticised vision of "the remote and reputedly beautiful region" (Unicorn, 10) does not bear much resemblance to what she has imagined since "she had not expected this solitude. She had not expected this appalling landscape" (Unicorn, 7). An idealised picture of the Irish countryside that Marian 
has in her mind in all likelihood results from the erroneous myth of the West, ${ }^{6}$ which has become one of the leading images of the twentieth-century Ireland after it gained its independence. The vast open spaces, predominant in this area, fill Marian with negative emotions: "she feared the rocks and the cliffs and the grotesque dolmen and the ancient secret things. Her two companions seemed no longer reassuring but dreadfully alien and even sinister. She felt, for the first time in her life, completely isolated and in danger" (Unicorn, 15-16). The feeling of isolation experienced by Marian proves that a seemingly open landscape can become a closed space, limited by the sea, the cliffs, as well as the long distance to the nearest town. Murdoch's presentation of the countryside corresponds well to the Gothic imagery, creating "a world shut off from the outside" (MacAndrew 1979: 34). Also, it conforms to Edmund Burke's idea concerning the source of the sublime. In accordance to his statements, a sublime landscape in order to reach the desired effect should be described as vast, solid and massive (Burke 1998: 157); whereas "absolute and entire solitude" caused by the exclusion from society is the source of pain, which is necessary for the feeling of the sublime to occur (Burke 1998: 90). The wide area of bogs and uninhabited fields intensify the atmosphere of seclusion and entrapment, instead of evoking the feeling of freedom usually associated with open spaces. Murdoch creates an illusion of an enormous geographical distance that seems almost impossible to cover and, if explored, threatens the trespassers with the possibility of getting lost.

Such a situation does actually take place in the novel when Effingham, overwhelmed with "too much space and privacy" (Unicorn, 107), loses his way on the bog: "Now all around him there was nothingness and nowhere ... He was, in this place, an intruder; and he felt the menace round about him of presences to whom human things were abhorrent ... The bog, the real bog, was a good way inland in this region, and between the bog and the Scarren was a long stretch of scrubby moor on which he had assumed he was still walking" (Unicorn, 162164). As an outsider, Effingham does not know the exact shortcut through the bog, and thus ends up struggling for his life. It is only thanks to Denis, a local man who works in Hannah's house, that he is rescued and shown the way back

6 The myth of the Irish West has been introduced by such writers as W.B. Yeats, who intended to revive Irish culture and the Irish language within the whole community. The Gaeltacht region, namely the area where Irish was still spoken at that time, has become mythologized as the epitome of Irishness. The unspoilt landscape of the western counties together with the simple life of local communities and their folklore have become a source of inspiration for many artists. To later generations of Irish writers, such as Liam O'Flaherty and Patrick Kavanagh, the romanticized image of the Irish province was a harmful one, as it presented a distorted picture of those areas by dissembling the poverty and unemployment among its inhabitants (Duffy 1997: 65-70). 
to the house. Therefore, it seems that some paths are reserved only for the locals, who are aware of the possible dangers connected with residing close to such hostile nature. However, the notion of isolationism in the Irish context cannot be limited solely to the geographical dimension, as it also alludes to more contemporary social and political aspects. In the first half of the twentieth century the whole policy of the Free State, which in 1959 was turned into the Republic of Ireland, was based on the idea of isolationism on political, economic, and social levels (Shirlow 1997: 91). It was not until 1973, when the Republic joined the European Community, that a substantial change was observable in the country's policy towards integration. When Murdoch was writing The Unicorn, Ireland was still suffering from the aftermath of its isolationist policy, and thus the feeling of hostility the newcomers encounter in the novel has its social justification as well.

Apart from the landscape, Gaze Castle embodies the feeling of solitude and entrapment: "a big grey forbidding house with a crenellated facade and tall thin windows which glittered now with light from the sea. The house had been built of the local limestone and reared itself out of the landscape, rather like dolmen, belonging yet not belonging" (Unicorn, 15). The very first words used to describe the house show how problematic the identity of its inhabitants is, who, similarly to the Anglo-Irish ascendancy, belong and yet do not belong to the place they occupy. The change of perspective does not alter much, as from the inside it seems uninviting, making Marian feel as if in a prison, in which she is constantly watched: "she had a big view across the valley to Riders and the sea ... the next moment she was looking at a man. He was standing on the terrace and looking straight into her eyes with lifted binoculars trained on Gaze" (Unicorn, 17). It is not only the inhabitants of the Riders mansion who spy on the Castle; the feeling of being watched comes from the inside of the Gaze as well. Hannah and Marian are constantly guarded by Gerald. The house itself also seems to hold a gaze on their every step, which comprises a typical Gothic technique, with the house being a reflection of the host's soul, thus fulfilling its master's will (MacAndrew 1979: 7). During the absence of Mr Crean-Smith, the master's and the villain's role is supposedly fulfilled by Gerald, who with time starts to resemble his master: "he has become like him. He has become him ... Gerald is Peter now. He has Peter's place, he is possessed by Peter, he even looks like Peter" (Unicorn, 229). As a result, Murdoch creates a gripping setting together with a traditional doppelganger figure, who, likewise to the house, becomes a reflection of the master's inner desires.

However, Murdoch does not exactly follow the pattern of the Gothic formula, since the mistress turns out not to be persecuted by her oppressor. At first sight, Hannah seems to be a Gothic heroine, whereas Mr Crean-Smith, a villain. Under the same misapprehension lives Marian, who after some time realises 
that Hannah is an enchantress, who makes everyone believe in her innocence as well as her self-imposed imprisonment (Johnson 1987: 102). Mr Crean-Smith, who is thought to be a patriarchal villain, appears to be a victim who had managed to escape death from Hannah's hands, but falls victim to her servant. A similar fate awaits her lover, Philip, who allegedly shoots himself by accident, but those who know her believe that despite being already dead at that time: "Hannah had claimed her last victim" (Unicorn, 269). This and other examples from the text justify a statement of Hannah being the oppressor not only to other people but, first and foremost, to herself. The untypical heroine, who only appears to be passive, actually has enough courage to self-fashion her own entrapment, to push her husband from the cliff or to commit suicide.

Thus, it comes as no surprise that no matter how much Marian tries to convince Hannah that: "she won't die if she goes outside the walls" (Unicorn, 120), she is not able to force the mistress to do it. The very attempt to cross the symbolic border between the inside and the outside is doomed to failure. After the attempted escape, Gerald explains to Marian: "What can you do for her, do you think, for her with the years and years of this solitude within her, by simply, as you say, 'showing her the outside'? Do you think this would mean anything? Do you think there really is, for Hannah, an inside and an outside anymore?" (Unicorn, 150). The years of self-entrapment have caused Hannah to forget about the existence of the outside world, so she no longer has any reason to free herself. In accordance with Bachelard, the dialectics of the inside and the outside is determined by the existence of this binary opposition in one's conscience. Once the exterior place loses its possibility of existence, like in Hannah's case, the contrast between here and there loses its ontological meaning (Bachelard 1994 [1958]: 218). By linking the dichotomy of imprisonment and freedom with the differentiation between the inside and the outside of the house, Murdoch shows how easily the meaning of the signified, namely, the inside and imprisonment, is lost, when the signifier ceases to exist, in this case the outside and freedom (Lefebvre 1991 [1974]: 147). Since Hannah has lost her perception of the outer space any attempt to rescue her is doomed to failure, because for her the idea of freedom does not carry the same meaning as it does for Marian.

Marian does not realise what the source of Hannah's mental entrapment is, and treats her mistress's behaviour as a lack of strength to fight against $\mathrm{Mr}$ Crean-Smith's oppression. So when it seems that Hannah has finally found enough courage to free herself, she does it just to commit suicide by falling over the cliff. Supposedly, Hannah appears to have realised that she cannot live locked up any more, but she does not belong to the outside world either. This being the case, her fate may be compared to Plato's parabola of the Cave, especially the way in which Deborah Johnson presents this motif following the words of Luce Irigaray: "the Platonic image of the Cave proposes a set of oppo- 
sitions, differences, discontinuities between outside and inside" (Johnson 1987: 88). However, the critic draws attention to the fact that Murdoch more often than not "deflects and alters the significance of those philosophical statements and metaphors which she inscribes into her narrative ... It is not surprising therefore that the Cave, itself an image of illusion, should have in her narratives its dark and mysterious double as a site of potential truth, the Sybil's Cave" (Johnson 1987: 86-87). This is why Hannah believes her life to be: "a dream. Do you know what part I have been playing? That of God, and do you know what I have been really? Nothing, a legend. A hand stretched out from the real world went through me as through a paper" (Unicorn, 218). According to Johnson, this and other instances show that Hannah's life is fictitious, lived in the cave, whereas the hand, responsible for the creation of the illusion, belongs to the man, who "textualises" her (Johnson 1987: 68). When Hannah is tempted enough to experience the reality, similarly to Tennyson's "Lady of Shalott", she faces death. This interpretation may be debatable, taking into consideration the fact that the mistress, even if in the world of fiction, still plays the role of God, who like the master of puppets plays with the lives of other people and her own as well. So Hannah's decision to end her life suggests her fear of facing the reality of her husband coming back ${ }^{7}$ and ruining her fictitious self rather than the impossibility of living in the real world. But when one scrutinizes Murdoch's philosophical works, one notices certain analogies concerning Platonism. To follow Conradi's line of argument, each of the characters of the novel represent a different theoretical approach towards the concept of freedom. Max Lejour is a typical Platonist, Marian is a feminist, whereas Effingham Cooper stands for existentialism (Conradi 1999: xxiv). The whole text has been structured so that it subverts the facile idea of freedom. This goes in accordance with a statement that, with the character of Hannah, Murdoch manifests her objection to the Romantic tradition, which gave rise to a neurotic modern novel full of characters who act according to their whims and desires instead of searching for the moral truth (Murdoch 1999: 217).

The unconventional ending is not the only untypical element of this seemingly Gothic novel. The house, although enormous seen from the outside, inside turns out to be cluttered and therefore lacking space. Instead of agoraphobic fears, it evokes claustrophobic feelings in those who are trapped inside (Johnson 1987: 69). Hannah is locked in the attic room after Marian's futile attempt to rescue the mistress: "Hannah was imprisoned not in the small centre, in the very heart of things; and perhaps it was there that Peter would keep her shut up now,

Johnson claims there is a connection between a man representing Plato's ideal and a woman as the man's shadow or reflection, which in this instance corresponds well to the double meaning of Hannah's fear of reality and her husband as one (Johnson 1987: 88). 
imprisoned in that room for ever" (Unicorn, 242). The way back down appears to be impossible for Hannah to trespass upon as the door is bolted. Marian soon experiences the feeling of entrapment as well, which she finds overwhelming: "The room was decrepit and ponderously old-fashioned like the one below, but immensely, almost too much, inhabited; and Marian felt herself shut in, almost menaced, by the circle of faded armchairs piled with books and papers" (Unicorn, 24). All the same, she constantly tries to rescue herself as well as her mistress, who seems to have not so much to have accepted her situation but yet again to have self-imposed it. The overwhelming feeling of claustrophobia is nothing new in the Gothic as well as Big House fiction, since the feeling of entrapment strengthens the effect of the sublime; whereas the remoteness and insularity of Ireland have always had a significant influence on the social relations within the local community. As Smyth points out: "the remoteness engendered by Ireland's insular position has had a fundamental influence on the nature of social relations, making for much intimacy and solidarity, but also introversion and bitterness" (Smyth 1997: 20). As a result, the tightness of social networks caused by the island's geographical limitations exerts the feeling of claustrophobia, especially among the newcomers.

Such dependence on the sublime interiority of the Castle is soon shared by Marian. After some time: "the narrow quiet life of Gaze, the prison life, suddenly seemed the best life of all" (Unicorn, 149). She finds it difficult to leave the inner space of Gaze Castle: "The garden was thick and magnetic behind her. Her desire to go out was gone. She was afraid to step outside. She stood paralysed in the gateway for some time" (Unicorn, 54-55). However, when Hannah dies, Marian eventually realises that she does not belong to this place and that it is high time to leave: "she would go back to all that now, to the real world ... and she too belonged out in the big well-lighted world" (Unicorn, 264-270). As the last words of the novel suggest, Marian has always been an outsider, so she is one of the few who are able to cross the symbolic border between the inner and the outer space of the house (Todd 1984: 56). In spite of being under the influence of the enclosed spaces of the Castle, she really never lost contact with the outside world, as she was communicating with her former partner via letters. Therefore, when the appropriate time came, she had enough strength to leave the house and to go back to the world she used to live in.

The women are not the only characters whose lives revolve around the question of freedom. The residents of Riders also share this feeling, but Max Lejour claims that it is not only enforcement that keeps people trapped. He suggests that: "guilt keeps people imprisoned in themselves" (Unicorn, 98). For him imprisonment does not lie in the exterior influence of Gerald or Mr CreanSmith, but rather within the psyche of an individual like Hannah. The dichotomy between imprisonment and freedom in the novel is often considered to be 
Murdoch's comment on different attitudes towards freedom presented by such philosophers as Plato or Jean Paul Sartre (Frankova 1995: 9). One hears the echo of their ideas in the words of Max: "In morals, we are all prisoners, but the name of our cure is not freedom" (Unicorn, 97) or Gerald's comment that "happiness is a weak and paltry thing and perhaps 'freedom' has no meaning" (Unicorn, 151). So the question arises whether any of the characters are genuinely free. If freedom may be defined in terms of the possibility to cross the border between the inside and the outside, as suggested in the novel, Marian does not lose her freedom during her stay in Gaze Castle. To answer this question, one has to take into consideration Murdoch's well-known lectures on the sublime, ${ }^{8}$ where she not only explains the Kantian idea of the experience of the sublime, but more importantly the writer enunciates her understanding of freedom. Murdoch, in accordance with Kant, treats the sublime as "an experience of the imagination and the reason in conflict ... experience of the sublime is a sort of moral experience, that is, an experience of freedom" (Murdoch 1999: 263) ${ }^{9}$. The sublime appears to be the realisation of the impossibility to reason away what one sees, nor is one able to comprehend the situation with the help of the imagination. Thus, freedom is the state of acceptance of the situation encountered. With The Unicorn Murdoch tries to convince the reader that "freedom is not choosing what is merely the move that we make when all is already lost. Freedom is knowing and understanding and respecting things quite other than ourselves" (Murdoch 1999: 284). ${ }^{10}$ This is what Marian is unable to comprehend, and thus her actions turn out to be fruitless and harmful for other characters.

Apart from Marian, Effingham and Gerald are the only people who without any limitations leave the Castle as well. Contrary to Marian's belief that "Gerald is in effect imprisoned too", he does not stay there all his time, as Pip states: "in between he is stepping on and off aeroplanes. The airport is less than two hours by car - and from there he can take off to anywhere in the world. I've heard of Gerald in Rome, in Paris" (Unicorn, 112). His constant contact with the outside world enables Gerald to maintain absolute control over the inner space of the house and to be free, although he claims himself that: "life is never really happy and free" (Unicorn, 151). For Bachelard, the supreme determinant of freedom in the dialectics of the inside and the outside is the object of the door. The person who is able to open the door is the real master of his or her life, and thus free

$8 \quad$ The essay "The sublime and the good" first appeared in the Chicago Review in 1959, and "The sublime and the beautiful revisited" was originally printed in the Yale Review in 1959. Both essays have been included in Iris Murdoch's collection of essays Existentialists and mystics. Writings on philosophy and literature published in 1997.

$9 \quad$ From "The sublime and the beautiful revisited", in Iris Murdoch's Existentialists and mystics. Writings on philosophy and literature, 261-286.

10 Op cit. 
(Bachelard 1994 [1958]: 224). This idea seems to be delineated in the scene when Hannah, locked in the attic, tries to open the door: "The handle of Hannah's door was quietly turning. It turned and then slipped back, and turned again. Hannah was trying to get out" (Unicorn, 242). She finally manages to do so and shows in the most excessive way that she is the master of her life by killing herself. But whether Hannah became a free person is still questionable, especially if one ponders on Marian's thoughts: "This was freedom, the freedom to love and move which she had so terribly lacked" (Unicorn, 201). The governess at some point realises what freedom means for her, or, more precisely, what made her feel that she had lost her freedom during her stay in Gaze Castle. In the case of Murdoch's novel, the possibility to move between the inside and the outside does not seem to decide about one's personal freedom. It is love, which allows Murdoch's characters to be free. "Love is the perception of individuals. Love is the extremely difficult realisation that something other than oneself is real. Love, and so art and morals, is the discovery of reality" (Murdoch 1999: 215) ${ }^{11}$ she writes in one of her theoretical essays when pondering on the sense of freedom. Hannah was deprived of love twice, when her husband turned out to be homosexual and when he locked her in the house so that she could not meet her lover, Phillip. As a result, she cannot regain her freedom as long as her husband lives. That is why she intended to kill him and later on does the same to herself.

Even though all these interpretations seem to pertain to an individual perception of freedom, Murdoch's presentation of the issue may also be read as a comment on the current events in Ireland. Although Murdoch always underlined that her writings do not touch upon political matters, her dispute over the meaning of freedom cannot be read outside Irish history and events such as the Easter Rising or The Troubles (Bradbury 1973: 237). Thus, The Unicorn, despite its Gothic machinery, is to a great extent rooted in realism, in social matters prevalent at that time (Tomczak 2009: 20, Frankova 1995: 11). Even if most of the characters seem to be leading their lives beyond reality and only from time to time happen to become a part of it, still, during these short moments, they do comment on the problems of their times and life in Ireland (Bradbury 1973: 233). For instance, the clash between Marian's active approach towards her life and Hannah's passivity alludes to the perception of Ireland as a place behind the times, and the Irish being a submissive people who accept their fate too easily. ${ }^{12}$ For Marian, who represents a modern woman, the mental and emotional imprisonment of the local people is difficult to comprehend. She wonders why such

11 From "The sublime and the good", in Iris Murdoch's Existentialists and mystics. Writings on philosophy and literature, 205-220.

12 As the governess states, "people can't be just shut up. We're not living in the Middle Ages", and hears a response from Denis that "we are here" (Unicorn, 60). 
characters as Denis: "big slow men, while not exactly hostile, entirely lacked the responsiveness of civilization" (Unicorn, 7) taking their limitations for granted. Following the existentialist approach, popular at the time of the novel's publication, The Unicorn shows that the Irish remain immune to the social changes observable in English society, because they are still immersed in their negative emotions, which have been accumulated by the past events and generations. All this makes the atmosphere claustrophobic, with the country being trapped in the past and an inconsolable guilt. However, with the hindsight of Murdoch's philosophy, one realises that the writer does not treat the behaviour of the Irish in terms of stagnation, but rather as a trace of their recognition of the state they find themselves in. The Irish appear too to have experienced the feeling of the sublime, namely, they realised that their vision of a free country did not meet the reality. Thus, the imagination came into conflict with reason, whereas reason failed to comprehend such experiences as the Troubles. To follow Murdoch's line of thought, only by accepting this state of affairs are Irish people able to become free.

In The Unicorn Iris Murdoch successfully enriches the traditional features of Gothic fiction with Irish overtones. A remote, pre-industrial country, surrounded by fields, cliffs, the sea and bogs, alludes to the Yeatsian myth of the West as an epitome of Irishness; whereas an old Victorian house refers to the trope of the Big House with the Anglo-Irish ascendancy suffering from the consequences of selfimposed isolationism. The terrifying events taking place in the dysfunctional family of the Crean-Smiths together with the hostile approach of the local people towards the English newcomer make the constant atmosphere of the sublime permeate throughout the story. However, Murdoch does not exactly follow the pattern of a Gothic plot since her heroine is living in a state of self-imposed imprisonment, which marks the writer's disregard for the Romantic tradition in favour of Plato's understanding of art. The ending signifies that the novel rather than just presenting a Gothic story adds its voice to a more universal dispute over the meaning of the idea of freedom, which for Murdoch is defined in terms of a mental state rather than a physical one. Whether her presentation of the notion of freedom may find its illustration in the Irish context remains an open question. Nevertheless, such a reading of The Unicorn sheds new light on the novel itself as well as on the unresolved issue of freedom among Irish people. 


\section{REFERENCES}

Alexander, Roy. 1989. Wildlife in the countryside. In Desmond Gillmor (ed.), The Irish countryside, 49-82. Dublin: Wolfhound Press.

Antonaccio, Maria. 2012. A philosophy to live by: Engaging Iris Murdoch. Oxford: Oxford University Press.

Bachelard, Gaston. 1994 [1958]. The poetics of space. Trans. Maria Jolas. Boston: Beacon Press.

Backus, Guy. 1986. Iris Murdoch. The novelist as philosopher. The philosopher as novelist. Frankfurt am Main: Peter Lang.

Bradbury, Malcolm. 1973. Possibilities. Essays on the state of novel. Oxford: Oxford University Press.

Broackes, Justin (ed.). 2011. Iris Murdoch. Philosopher. Oxford: Oxford University Press.

Burke, Edmund. 1998. A philosophical enquiry into the sublime and beautiful and other prerevolutionary writings. London: Penguin Classics.

Byatt, A.S. 1976. Iris Murdoch. London: Longman Group.

Conradi, Peter J. 1999. Editor's preface. In Iris Murdoch, Existentialists and mystics. Writings on philosophy and literature, $\mathrm{xix}-\mathrm{xxx}$. London: Penguin Books.

Conradi, Peter. J. 2001. Iris Murdoch. A life. London: Harper Collins Publishers.

Conradi, Peter J. 2010. Laughing at something tragic: Murdoch as anti-moralist. In Anne Rowe \& Avril Horner (eds.), Iris Murdoch and morality, 56-69. London: Palgrave Macmillan.

Duffy, Patrick J. 1997. Writing Ireland. Literature and art in the representation of Irish place. In Brian Graham (ed.), In search of Ireland. A cultural geography, 64-83. London \& New York: Routledge.

Fiérobe, Claude. 1991. Irish homes in the work of C.R. Maturin. In Jacqueline Genet (ed.), The Big House in Ireland. Reality and representation, 71-84. Dingle: Brandon Book Publishers.

Foster, John Wilson. 2005. Introduction. In John Wilson Foster (ed.), The Cambridge companion to the Irish novel, 1-21. Cambridge: Cambridge University Press.

Frankova, Milada. 1995. Human relationships in the novels of Iris Murdoch. Brno: University of Brno.

Genet, Jacqueline. 1991. Introduction. In Jacqueline Genet (ed.), The Big House in Ireland. Reality and representation, ix-xii. Dingle: Brandon Book Publishers.

Horner, Avril. 2010. 'Refinements of evil': Iris Murdoch and the gothic. In Anne Rowe \& Avril Horner (eds.), Iris Murdoch and morality, 70-84. London: Palgrave Macmillan.

Johnson, Deborah. 1987. Iris Murdoch. Bloomington \& Indianapolis: Indiana University Press.

Kilfeather, Siobhan. 2005. The gothic novel. In John Wilson Foster (ed.), The Cambridge companion to the Irish novel, 78-96. Cambridge: Cambridge University Press.

Kreilkamp, Vera. 1998. The Anglo-Irish novel and the Big House. Syracuse \& New York: Syracuse University Press.

Lefebvre, Henri. 1991 [1974]. The production of space. Trans. Donald Nicholson-Smith. Oxford: Blackwell.

MacAndrew, Elizabeth. 1979. The gothic tradition in fiction. New York: Columbia University Press.

De Melo Araujo, Sofia \& Fatima Vieira (eds.). 2011. Iris Murdoch. Philosopher meets novelist. Newcastle upon Tyne: Cambridge Scholars Publishing.

Murdoch, Iris. 1966. The Unicorn. London: Penguin Books.

Murdoch, Iris. 1999. Existentialists and mystics. Writings on philosophy and literature. Peter Conradi (ed.). London: Penguin Books. 
Rauchbauer, Otto. 1992. The Big House and Irish history: An introductory sketch. In Otto Rauchbauer (ed.), Ancestral voices. The Big House in Anglo-Irish literature, 1-16. Hildesheim: Georg Olms Verlag.

Shirlow, Peter. 1997. Class, materialism and the fracturing of traditional alignments. In Brian Graham (ed.), In search of Ireland. A cultural geography, 87-107. London \& New York: Routledge.

Smyth, William J. 1997. A plurality of Irelands. Regions, societies and mentalities. In Brian Graham (ed.), In search of Ireland. A cultural geography, 19-42. London \& New York: Routledge.

Todd, Richard. 1984. Iris Murdoch. London \& New York: Methuen.

Tomczak, Anna Maria. 2009. Reading class. Non-verbal communication as a reflection of middle class attitudes and behaviours in selected novels of Iris Murdoch. Białystok: Białystok University Press.

Walpole, Horace. 1968. The castle of Otranto. In Peter Fairclough (ed.), Three gothic novels, 37148. 